more likely. He was kept alive for $3 \frac{1}{2}$ weeks with blood transfusions, but at no time was there any evidence of regeneration from the marrow. Post-mortem showed the classical picture of complete bone marrow aplasia and multiple submucous haemorrhages.

My thanks are due to Colonel G. T. Gimlette, A.M.S., for permission to publish this case, and to Sergt. M. Suart, R.A.M.C., for his painting of the fundus.

\title{
REFERENCE
}

DUKE-ELdER. - Textbook of Ophthalmology, Vol. III.

\section{HAEMORRHAGE FROM THE CONJUNCTIVA* Notes on a case of capillary angioma}

\author{
BY \\ J. Pendleton White \\ GLASGOW
}

ON November 25, 1944, a married woman, aged 40 years, complained of having suffered on two occasions from bloody tears. About six weeks previously during the evening she felt something hot running from her right eye, and on applying her handkerchief she noticed that it was stained with blood. The onset had no association with menstruation, and the patient was a healthy woman entirely free from any hysterical signs or symptoms. There was no history of injury, and none of haemophilia in the family. Examination of the blood revealed no abnormality. The bleeding on the first occasion lasted for a few minutes and was arrested by tightly applying her handkerchief to her eyelids.

She had one subsequent attack about a month after the first. On everting the right upper eyelid a small reddish growth about $3 \mathrm{~mm}$. by $2 \mathrm{~mm}$. was noted on the palpebral conjunctiva near the superior margin of the tarsus. This was seen by the slit-lamp to be highly vascular. The growth was excised along with a piece of the tarsus, and a stitch inserted. There was no subsequent haemorrhage.

On histological examination the excised tissue showed the following characteristics.

It had a thickness of $1 \mathrm{~mm}$. It contained the Merbomian glands and a richly infiltrated fatty sub-conjunctival tissue. The

* Received for Publication, May 19, 1945. 
epithelium was flat and thin in the tarsal region, and was well preserved in the area of the fornix. Here the conjunctiva was haid in many folds, and the epithelium was full of goblet cells. Most of these folds were vascularised normally, but one especially was practically filled (Fig.) by a convolution of thin walled vessels of 12-30 micron. The reticulum between the capillaries of the angioma was full of lymphocytes. Where the capillaries reached the epithelium it appeared to be reduced locally to one row.

It would appear therefore that the capillary angioma was the source of the haemorrhage.

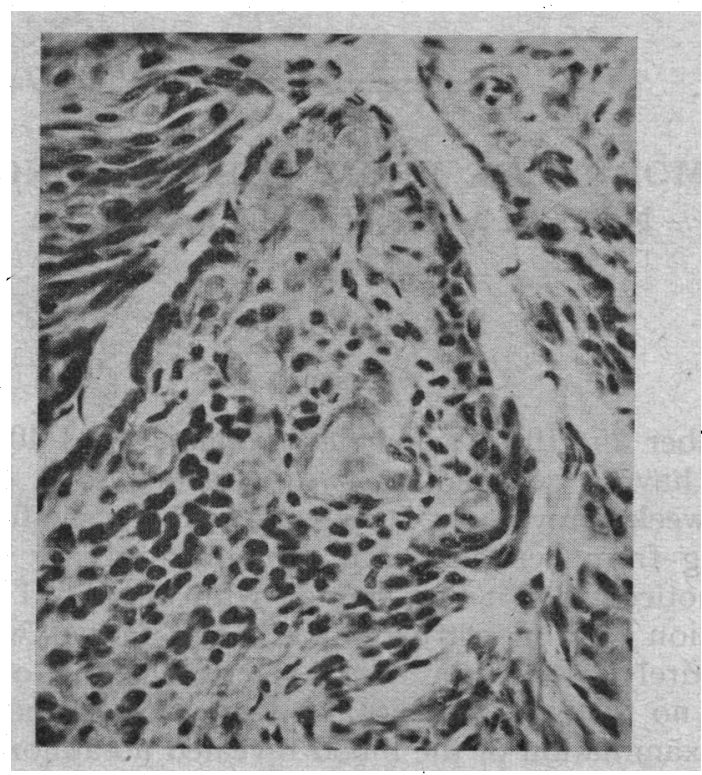

Conjunctival angiomata are comparatively rare, but if the conjunctiva is studied carefully with the slit-lamp some small ones are sometimes noted.

A lesion of the very thin epithelium over some of the thin-walled vessels may easily lead to haemorrhage. It may even be that slight pressure upon the eyelid might suffice to rupture the superficially unprotected angioma.

An angioma may occasionally show a swelling similar to that of the corpus cavernosum and this could easily lead to haemorrhage.

The literature records many interesting cases of "bloody tears," the most interesting being that of the girl Therese von Konnersreuth published by Hyuek (1932) who during " the 
ecstasy of Good Friday " wept tears of blood. This was regarded as a hysterical manifestation.

The main point of interest in my case is that the source of the ' haemorrhage could be so definitely demonstrated. A case of severe haemorrhage from an ulcerated naevus leading to a state of collapse was recorded by Jessop in 1898 .

Apart from injury bleeding from the conjunctiva must be a somewhat rare occurrence. In the course of a very long experience in an industrial area I have never met with this before. I have everted thousands of eyelids in a population exposed to frequent minor injuries, and I have never seen a capillary angioma situated on the palpebral conjunctiva which could be attributed to trauma. It is unlikely, therefore, that this angioma had any association with injury.

I am indebted to Professor Loewenstein for his histological notes and to Mr. John Watt for his technical assistance. My thanks are also due to Professor W. J. B. Riddell for kindly placing the resources of the Tennent Institute at my disposal.

\section{BIBLIOGRAPHY}

HyUex. KonNersReuth (Trans. Shepherd), London, 1932.

JESSOP.-Trans. Ophthal. Soc. U.K., Vol: XV, p. 64, 1895.

\section{A CORNEAL GRAFT OPERATION FOR RECURRENT PTERYGIUM*}

BY

Lieut. J. L. REIS, Polish A.M.C.

OPHTHALMIC SPECIALIST, POLISH

GENERAL HOSPITAL, C.M.F.

THE common methods of pterygium operations aim at the separation and displacement of the pterygium from the cornea. This leaves an open wound of the cornea, where a cicatricial opacity, with tendency to vascularisation; develops. It is not unusual for this corneal scar to get covered with conjunctiva, thus forming a pseudopterygium.

Not infrequently the pterygium recurs and has the same appearance as the stationary pseudopterygium but differs from the latter by its tendency to grow and that it has no marginal folds. So the results of those operations are not very satisfactory, both from the cosmetic as well as from the functional point of view.

* Received for publication April 19, 1945. 